\title{
TINGKAT EMPATI MAHASISWA PROGRAM STUDI BIMBINGAN DAN KONSELING UNIVERSITAS KANJURUHAN MALANG
}

\section{Laily Tiarani Soejanto}

${ }^{1}$ Fakultas Ilmu Pendidikan, Universitas Kanjuruhan Malang

\begin{abstract}
Abstratc
Empathy and the ability to see things from the client's perspective is also important, as is the counsellor's ability to demonstrate an investment of their time and full attention. The purpose of this study is 1) to know the level of empathy of students Guidance and Counseling Program University of Kanjuruhan Malang; 2) To describe the difference of empathy level of students based on force and gender. The subjects of this study are students Guidance and Counseling Program University of Kanjuruhan Malang class of 2013, 2014 and 2015. The research instrument used is empathy scale which is then processed by using descriptive statistic, Test-t and Anova. The result of this research is 57,5\% of students are at high empathy level, 35,7\% student are in moderate empathy level, and 6,8\% student student is a low; 2) There is no significant difference of empathy level of students based on force 2) There is a significant difference of empathy level based on gender.
\end{abstract}

Keyword:Empathy,Guidance and Counseling Program, Gender

Copyright (C) 2016 IICET (Indonesia) - All Rights Reserved Indonesian Institute for Counseling, Education and Theraphy (IICET)

\section{PENDAHULUAN}

Sosok utuh kompetensi konselor mencakup kompetensi akademik dan profesional sebagai satu keutuhan. Kompetensi akademik merupakan landasan ilmiah dari kiat pelaksanaan pelayanan profesional bimbingan dan konseling. Kompetensi akademik merupakan landasan bagi pengembangan kompetensi profesional, yang meliputi: (1) memahami secara mendalam konseli yang dilayani, (2) menguasai landasan dan kerangka teoretik bimbingan dan konseling, (3) menyelenggarakan pelayanan bimbingan dan konseling yang memandirikan, dan (4) mengembangkan pribadi dan profesionalitas konselor secara berkelanjutan. Unjuk kerja konselor sangat dipengaruhi oleh kualitas penguasaan ke-empat kompetensi tersebut yang dilandasi oleh sikap, nilai, dan kecenderungan pribadi yang mendukung. Kompetensi akademik dan professional konselor secara terintegrasi membangun keutuhan kompetensi pedagogik, kepribadian, sosial, dan professional. (Abkin, 2007).

Menurut Rogers (Corey, 2005) ada tiga karakteristik yang harus dimiliki oleh konselor yaitu: 1) congruence, 2) unconditional Positive regard, 3) Emphaty. Berdasarkan tiga karakteristik tersebut diharapkan kinerja konselor dalam memberikan layanan bimbingan dan konseling memiliki motif altruistik, sikap empatik, menghormati keragaman, serta mengutamakan kepentingan konseli. Empati menjadi hal yang sangat penting dalam pelaksanaan pelayanan bimbingan dan konseling, dalam pelaksanaan konseling empati menjadi tonggak awal dalam menciptakan raport antara konselor dan konseli, penghargaan tanpa syarat antara konselor dan konseli, menciptakan hubungan saling percaya antara konselor dan konseli. Empati merupakan kemampuan untuk merasakan keadaan emosional orang lain, merasa simpatik, dan mencoba menyelesaikan masalah serta mengambil perspektif orang lain. (Baron dan Byrne, 2005).

\footnotetext{
*Telp atau Alamat Email Koresponden :

* ${ }^{1}$ Tel.: +628123387780. E-mail address : lailytiarani@unikama.ac.id
} 
Empati dalam proses konseling dapat membuat konseli lebih didengar, dihargai dan merasakan bahwa ada orang lain yang mampu untuk merasakan apa yang dirasakan oleh dirinya pada saat itu. Sehingga konselor yang memiliki sikap empati mampu menempatkan dirinya lebih dalam apa yang dirasakan oleh konseli. Berdasarkan hal tersebut, empati menjadi penting untuk dikembangkan oleh konselor yang akan membantu memfasilitasi konseli dalam menyelesaikan permasalahan yang dihadapi, dan diperlukan latihan untuk menampilkan sikap empati sehingga pelayanan konseling yang dilakukan menjadi lebih efektif. Empati secara akurat akan membantu konselor untuk mampu secara utuh menempatkan dirinya dalam proses konseling (Handari, 2016).

Menurut Rogers (Corey, 2005) empati konselor sebagai salah satu faktor kunci yang membantu konseli untuk memecahkan masalah personalnya. Ketika seseorangberempati kepada orang lain, maka akan meletakkan dirinya "in their shoes", melihat dunia dari mata mereka, membayangkan bagaimana bila menjadi mereka, dan berusaha merasakan apa yang mereka rasakan. Faktor sosial dan budaya (seperti gender, etnis, perbedaan kultur) mempunyai pengaruh dalam pengekspresian emosi. Faktor ini mempengaruhi cara bagaimana konselor merespon secara emosional. Jika konseli merasa dimengerti, maka mereka akan lebih mudah membuka diri untuk mengungkapkan pengalaman mereka dan berbagi pengalaman tersebut dengan orang lain. Konseli yang membagi pengalamannya secara mendalam memungkinkan untuk menilai kapan dan di mana mereka membutuhkan dukungan, dan potensi kesulitan yang membutuhkan fokus untuk rencana perubahan.

Sikap empati yang dimiliki oleh konselor menentukan keberhasilan dalam proses konseling, penelitian yang dilakukan oleh Mudjijanti (2012) mengungkapkan bahwa motivasi konseli dan sikap empati konselor memiliki pengaruh yang signifikan dalam proses konseling. Selain mempengaruhi keberhasilan proses konseling sikap empati konselor yang ditunjukkan oleh konselor dapat mempengaruhi penerimaan siswa hasil penelitian yang dilakukan oleh Andangsari (2010) menyimpulkan bahwa terdapat hubungan yang memadai antara penerimaan diri siswa dengan empati konselor di SMA Negeri 8 Batanghari yaitu sebesar 0,46. Hal ini berarti empati konselor memiliki pengaruh terhadap penerimaan diri siswa itu sendiri. Oleh karena itu disarankan agar pada konselor agar dapat mempertahankan dan meningkatkan empati diri terhadap orang lain terutama kepada siswa sehingga dapat meningkatkan penerimaan diri siswa dan pelaksanaan bimbingan konseling pun dapat berjalan dengan baik.

Empati memiliki korelasi yang sangat erat dengan perilaku pro-sosial. Siswa dapat berbagi perasaan dengan orang lain dalam suasana suka maupun duka, kesediaan memberikan bantuan kepada orang lain baik materiil maupun moril dan juga kesediaan untuk bekerjasama dengan orang lain demi tercapainya suatu tujuan. Empati juga dapat meningkatkan harga diri individu. Richard (dalam Jones, 2011) menyatakan bahwa hubungan sosial merupakan media berkreasi dan menyebabkan tumbuhnya rasa harga diri dalam diri seseorang. Berdasarkan paparan di atas dapat disimpulkan bahwa empati merupakan sumber dari perubahan sikap individu (Irimia, 2010).

Mengingat pentingnya sikap empati yang dimiliki konselor maka sebagai Lembaga Pendidikan Tenaga Kependidikan (LPTK), Program Studi Bimbingan dan Konseling Universitas Kanjuruhan Malang diharapkan mampu menyiapkan calon konselor yang memiliki sikap empati. Penelitian Tingkat Empati Mahasiswa Bimbingan dan Konseling Universitas Kanjuruhan Malang menjadi studi awal untuk mengembangkan program pengembangan, program kuratif dan program antisipatif yang berkaitan dengan empati

\section{METODOLOGI PENELITIAN}

Rancangan penelitian ini adalah penelitian deskriptif, penelitian deskriptif merupakan metode yang paling sering digunakan untuk penelitian yang bertujuan menjelaskan suatu peristiwa. Menurut Sugiyono (2011) penelitian deskriptif adalah sebuah penelitian yang bertujuan menjabarkan suatu keadaan atau fenomena yang terjadi dengan menggunakan prosedur ilmiah untuk menjawab masalah secara aktual. Dalam penelitian ini akan dijabarkan tingkat empati mahasiswa Program Studi Bimbingan dan Konseling Universitas Kanjuruhan Malang dan mendeskripsikanperbedaan tingkat empati mahasiswa Program Studi Bimbingan dan Konseling Universitas Kanjuruhan Malang berdasarkan angkatan serta jenis kelamin.

Instrumen penelitian yang digunakan untuk mengungkap tingkat empati mahasiswa adalah skala empati yang diadaptasi dari Scale of the Empathy Questionnare berdasarkan pada aspek-aspek empati milik Davis (1983. Aspek-aspek empati yang diukur meliputi: Komponen kognitif dan afektif dan masing-masing memiliki dua aspek yaitu: komponen kognitif terdiri dari Perspective Taking (PT) dan fantacy (FS), sedangkan komponen afektif meliputi EmpathicConcern (EC) dan Personal Distress (PD). Skala Empati ini telah mmenuhi syarat validitas dan reabilitas, dari hasil uji validitas skala empati dapat diketahui bahwa keseluruhan item termasuk dalam kategori valid sebab skor korelasi item lebih besar dari r tabel 0,266 dan berkisar antara 0,307 sampai dengan 0,762. Sedangkan untuk hasil uji reliabilitas skala empati menunjukkan 
nilai CronbachAlpha sebesar 0,949. Hal ini menunjukkan bahwa skala empati adalah reliabel, karena nilai CronbachAlpha $0,949>0,80$.

Populasi penelitian ini adalah seluruh mahasiswa Program Studi Bimbingan dan Konseling Fakultas Keguruan dan Ilmu Pendidikan Universitas Kanjuruhan Malang angkatan 2013, angkatan 2014 dan angkatan 2015.

Tabel 2. Jumlah Mahasiswa Program Studi Bimbingan dan Konseling

\begin{tabular}{cc}
\hline Angkatan & Jumlah \\
\hline 2013 & 73 \\
2014 & 70 \\
2015 & 71 \\
Total & 215 \\
\hline
\end{tabular}

Untuk sampel penelitian yang akan diambil adalah apabila subjek kurang dari 100, lebih baik diambil semua sehingga penelitian merupakan penelitian populasi. Tetapi, jika subjeknya besar, dapat diambil antara 10-15\% atau 20-25\% atau lebih (Arikunto: 2006). Dalam penelitian ini sampel yang akan diambil sebanyak 25\% dari jumlah keseluruhan mahasiswa Program Studi Bimbingan dan Konseling Universitas Kanjuruhan Malang angkatan 2013, 2014 dan 2015 yaitu sebanyak 53,75 responden atau dibulatkan menjadi 54 responden.

Metode pengambilan sampel dilakukan dengan metode teknik sampling purposive yaitu "teknik penentuan sampel dengan pertimbangan tertentu". Teknik ini bisa diartikan sebagai suatu proses pengambilan sampel dengan menentukan terlebih dahulu jumlah sampel yang hendak diambil, kemudian pemilihan sampel dilakukan dengan berdasarkan tujuan-tujuan tertentu, asalkan tidak menyimpang dari ciri-ciri sampel yang ditetapkan. (Sugiyono,2011). Sampel dalam penelitian ini adalah mahasiswa Program Studi Bimbingan dan Konseling angkatan 2014, angkatan 2014, angkatan 2015.Untuk menjawab pertanyaan penelitian tentang tingkat empati mahasiswa Program Studi Bimbingan dan Konseling Universitas Kanjuruhan Malang, data diolah dengan menggunakan statistik deskriptif kurva normal, dengan menentukan Mean (rata-rata) dan Standar deviasi skor hipotetik. Kemudian dibuat kategori berdasarkan skor dalam rentangan jumlah skor ratarata dan deviasi. Skor yang yang berada di dalam kategori tertentu di hitung persentase mahasiswa yang ada dalam ketegori tersebut. Untuk membuktikan hipotesis penelitian tentang perbedaan tingkat empati mahasiswa Program Studi Bimbingan dan Konseling Universitas Kanjuruhan Malang berdasarkanangkatan dan jenis kelamin data diolah dengan mengunakan rumus uji beda dua Mean (Uji - t) dan annova.

\section{HASIL DAN PEMBAHASAN}

A. Tingkat Empati Program Studi Bimbingan dan Konseling Mahasiswa Universitas Kanjuruhan Malang

Berdasarkan hasil penelitian diperoleh data sebagai berikut: 57,5\% mahasiswa Program Studi Bimbingan dan Konseling Universitas Kanjuruhan Malang berada pada tingkat empati tinggi, 35,7\% mahasiswa mahasiswa Program Studi Bimbingan dan Konseling berada pada tingkat empati sedang, dan 6,8\% siswa mahasiwa berada pada tingkat empati rendah. Sehingga rata-rata mahasiswa Program Studi Bimbingan dan Konseling Universitas Kanjuruhan Malang berada pada tingkat empatit tinggi (57,5\%).

\section{Tingkat Empati Mahasiswa}

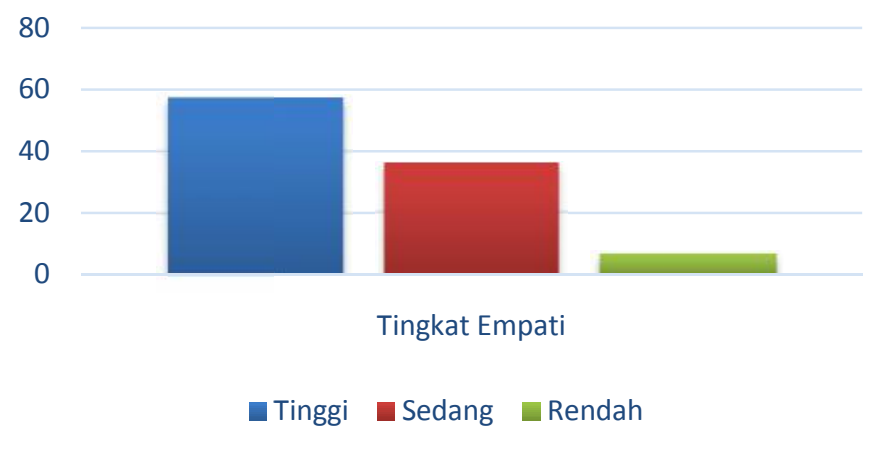




\section{B. Tingkat Empati Program Studi Bimbingan dan Konseling Mahasiswa Universitas Kanjuruhan Malang Berdasarkan angkatannya}

Hasil penelitian ini menggambarkan bahwa 34,3\% Mahasiswa angkatan 2013 berada pada tingkat empatitinggi, 61,3\% Mahasiswa berada pada tingkat empatisedang, 4,4 \% Mahasiswa berada pada tingkat empati rendah. Dapat disimpulkan bahwa mahasiswa angkatan 2013 yang mempunyai prosentase paling banyak adalah mahasiswa yang berada dalam kategori tingkat empatisedang (61,3\%). Untuk angkatan 2014 diperoleh hasil sebagai berikut 82,6 \% Mahasiswa berada pada tingkat empati tinggi, 12,7 \% Mahasiswa berada pada tingkat empatisedang, 4,7\% Mahasiswa berada pada tingkat empatirendah. Dapat disimpulkan bahwa mahasiswa yang mempunyai prosentase paling banyak adalah mahasiswa yang berada dalam kategori tingkat empati tinggi $(82,6 \%)$.

Hasil penelitian untuk Angkatan 2015 adalah sebagai berikut 53,6\% Mahasiswa berada pada tingkat empati tinggi, 35,4 \% Mahasiswa berada pada tingkat empati sedang, $11 \%$ Mahasiswa berada pada tingkat empati rendah. Dapat disimpulkan bahwa mahasiswa yang mempunyai prosentase paling banyak adalah mahasiswa yang berada dalam kategori tingkat empati tinggi (53,6\%). Pengujian hipotesis menggunakan uji t dua sampel independen menunjukkan t hitung adalah 0,371 dengan signifikansi 0,456. Oleh karena signifikansi $0,456<0,05$ maka diperoleh kesimpulan bahwa tidak ada perbedaan yang signifikan antara Tingkat Empati Program Studi Bimbingan dan Konseling Mahasiswa Fakultas Ilmu Pendidikan Universitas Kanjuruhan Malang berdasarkan angkatannya

\section{Tingkat Empati Program Studi Bimbingan dan Konseling Mahasiswa Universitas Kanjuruhan Malang Berdasarkan Jenis Kelamin \\ Hasil penelitian tentang Tingkat Empati Program Studi Bimbingan dan Konseling Mahasiswa} Universitas Kanjuruhan Malang berdasarkan jenis kelamin menunjukkan 63,2\% mahasiswa wanita berada pada tingkat empati tinggi, dan $34,1 \%$ mahasiswa wanita berada pada tingkat empati sedang. Sedangkan tingkat empati rendah untuk mahasiswa wanita sebesar $(2,7 \%)$. Demikian dapat disimpulkan bahwa rata-rata mahasiswa wanita berada pada tingkat empati sangat tinggi $(63,2 \%)$. Sedangkan untuk mahasiswa laki-laki menunjukkan $41,9 \%$ berada pada tingkat empati tinggi, 54,8\% mahasiswa laki-laki berada pada tingkat empati sedang, dan 2,3\% mahasiswa laki-laki berada pada tingkat empati rendah. Dengan demikian dapat disimpulkan bahwa rata-rata mahasiswa berada pada tingkat empati sedang yaitu 54,8\%. Pengujian hipotesis menggunakan uji t dua sampel independen menunjukkan nilai t hitung adalah -2,779 dengan signifikansi 0 , 027. Oleh karena signifikansi $0,027<0,05$ maka diperoleh kesimpulan bahwa terdapat perbedaan yang signifikan antara Tingkat Empati Program Studi Bimbingan dan Konseling Mahasiswa Universitas Kanjuruhan Malang berdasarkan jenis kelamin

\section{PEMBAHASAN}

Empati memainkan peran penting dalam hubungan pribadi. Empati menunjuk pada kemampuan untuk melihat sesuatu melalui cara pandang dan perasaan orang lain. Empati berupaya untuk melepaskan perspektif dirinya sendiri dan mengambil perspektif orang lain, sehingga orang dapat mengetahui dan memahami apa yang menjadi masalah orang lain.Dalam proses konseling, empati merupakan sikap positif yang ditunjukkan konselor terhadap konseli, berupa kesediaan konselor untuk menempatkan dirinya pada posisi konseli, tanpa dirinya sendiri lebur didalamnya, sehingga konselor dapat melihat realita dengan cara, sudut pandang, pengertian, dan pengalaman emosional pribadi konseli. Ini dapat terjadi jika konselor dapat menerima konseli apa adanya, tidak melakukan penilaian atau menghakimi.

Berdasarkan hasil penelitian menggambarkan bahwa mahasiswa Program Studi Bimbingan dan Konseling Universitas Kanjuruhan Malang memiliki tingkat empati yang tinggi, hal tersebut dapat terjadi karena pengalaman yang diperoleh mahasiswa Menurut Davis (1983) empati merupakan suatu reaksi individu pada saat ia mengamati pengalaman orang lain yang terdiri dari komponen kognitif dan afektif. Empati dibangun pada lingkup kesadaran, sehingga makin terbuka terhadap emosi kita sendiri, makin terampil kita dalam memahami perasaan orang lain. Terdapat beberapa faktor yang mempengaruhi empati yaitu sosialisasi yang memungkinkan seseorang mengalami sejumlah emosi orang lain, kemampuan kognitif untuk melihat sesuatu dari sudut pandang orang lain dan proses belajar yang mendorong siswa untuk lebih banyak membantu orang lain dengan cara yang lebih tepat.

Perbedaanbudaya dapat mengakibatkan perbedaan tingkat empati antara mahasiswa laki-laki dan perempuan, pernyataan ini didukung oleh penelitian yang dilakukan oleh Martha (1990) mengenai perbedaan empati berdasarkan gender mengungkapkan bahwa ada steoreotype budaya lama bahwa perempuan lebih empatik daripada pria. Penelitian lain yang dilakukan oleh Webb dan Tousaint (dalam Davies, 1999) 
mengatakan bahwa beberapa penelitian menunjukkan bahwa anak perempuan lebih banyak menunjukkan perilaku prososial dan empati terhadap orang lain, dibandingkan anak laki-laki. penelitian sebelumnya juga menunjukkan bahwa wanita lebih empatik dan relasional daripada pria (misalnya, Eisenberg \& Lennon, 1983; Lennon \& Eisenberg, 1987).

\section{SIMPULAN DAN SARAN}

Berdasarkan hasil penelitian ini dapat disimpulkan bahwa 1) 57,5\% mahasiswa Program Studi Bimbingan dan Konseling Universitas Kanjuruhan Malang berada pada tingkat empati tinggi, 35,7\% mahasiswa mahasiswa Program Studi Bimbingan dan Konseling berada pada tingkat empati sedang, dan 6,8\% siswa mahasiwa berada pada tingkat empati rendah; 2) Tidak ada perbedaan yang signifikan tingkat empati mahasiswa Program Studi Bimbingan dan Konseling Universitas Kanjuruhan Malang berdasarkan angkatan 2) Ada perbedaan yang signifikan tingkat empati mahasiswa Program Studi Bimbingan dan Konseling Universitas Kanjuruhan Malang berdasarkan jenis kelamin

Saran penelitian 1) Bagi Lembaga, dapat memanfaatkan hasil penelitian ini sebagai sumber informasi awal dalam pengembangan program-program jangka pendek maupun jangka panjang dalam rangka peningkatan, pemeliharaan empati mahasiswa Program Studi Bimbingan dan Konseling Universitas Kanjuruhan Malang Universitas Kanjuruhan Malang ; 2) Bagi Pusat Konseling dan Testing, data-data yang ditemukan pada penelitian ini dapat menjadi informasi awal bagi Pusat Konseling dan Testing khususnya dalam mengembangkan program-program peningkatan mahasiswa Program Studi Bimbingan dan Konseling Universitas Kanjuruhan Malang Universitas Kanjuruhan Malang.; 3) Bagi Penelitian lanjut, data-data yang ditemukan pada penelitian ini dapat menjadi informasi awal bagi tim peneliti untuk mengembangkan berbagai penelitian lanjutan di lingkup yang lebih luas berkenaan dengan aspek empati.

\section{DAFTAR RUJUKAN}

ABKIN. 2007. Penataan Pendidikan Profesional Konselor dan Layanan Bimbingan dan Konseling dalam Jalur Pendidikan Formal. Jakarta : Depdiknas.

Andangsari. 2010. Perilaku Kerja Guru Bimbingan dan Konseling Laki-Laki dan Perempuan Tingkat SLTA Di Jakarta. Jurnal Humaniora. Vol 1. No 1 49-60.

Arikunto, S. 2006. Prosedur Penelitian Suatu Pendekatan Praktik. Jakarta: Rineka Cipta.

Corey, G.2005. Teori Dan Praktek Konseling \& Psikoterapi. Bandung: Pt Refika Aditama

Davis, M.H. 1983. Measuring Individual Differences in Empathy. Journal of

Personality and Social Psychology. Vol 132. No. 2 397-410.

Handari. 2016. Empati Sebagai Pengembangan Seni Konseling Untuk Efektifitas Pelayanan Konseling. Lentera. Vol XVIII. No 1 49-63.

Irimia C. 2010. Empathy As A Source Of Attitude Change. Contemporary Readings in Law and Social Justice Volume 2. Romanian Society of Psychoanalysis.

Jones. 2011. Teori dan Praktik Konseling dan Terapi. Yogyakart: Pustaka Pelajar.

Latipun. 2001. Psikologi Konseling. Malang: UMM Press

Mudjijanti. 2012. Pengaruh Motivasi dan Sikap Empati Konselor Terhadap Keberhasilan Proses Konseling. Widya Warta No 2 176-194.

Sugiyono. 2011. Metode Penelitian Kuantitatif, kualitatif dan $R \&$ D. Bandung: Alfabeta.

Toussant L, Webb JR. 2015. Gender Differences In The Relationship Between Emphaty And Forgiveness. J Soc Psychol; 145; 673-685 